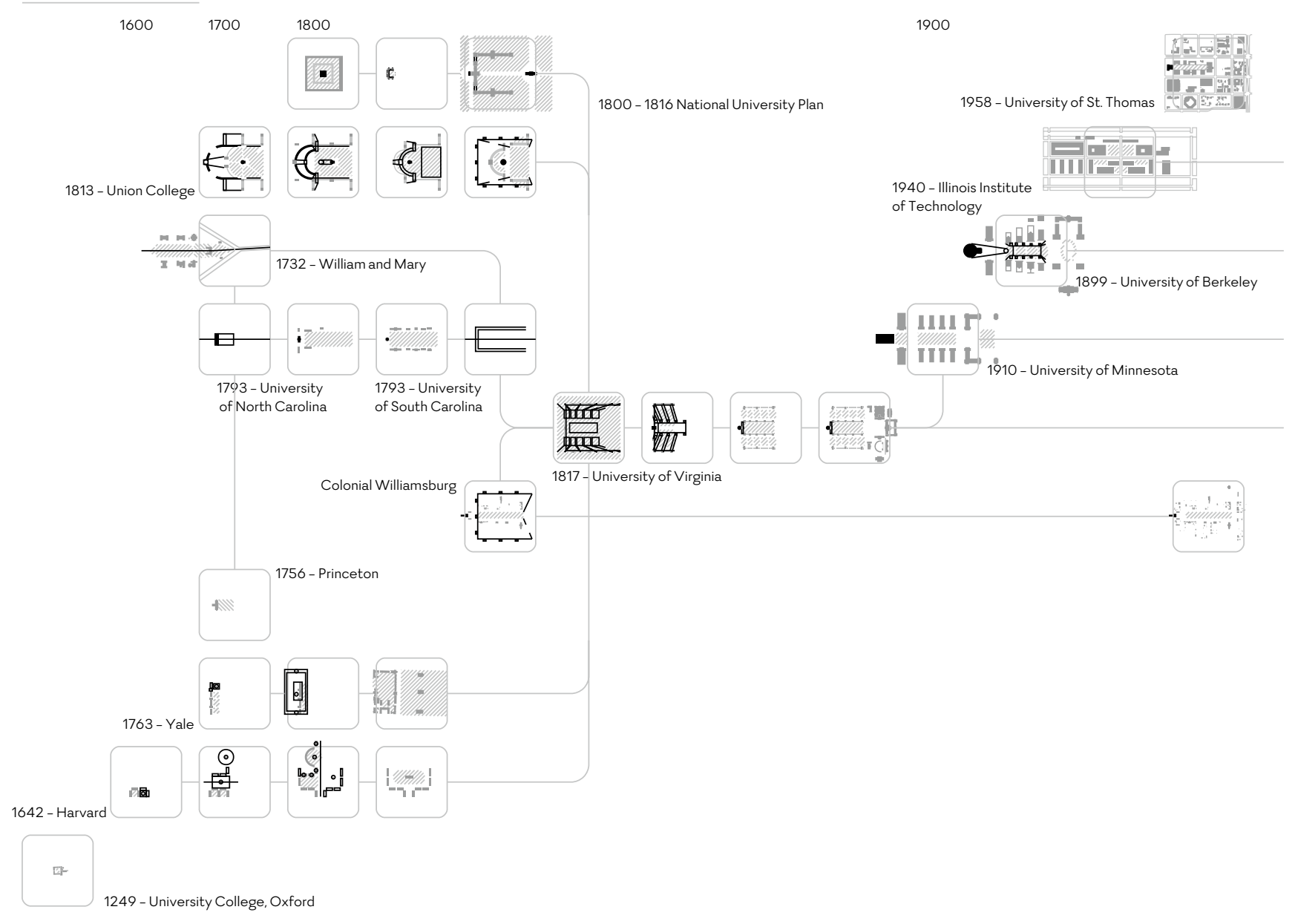

\title{
CAMPUS DEVELOPMENT
}

VÝVOJ KAMPUSOV

Author Autor: Peter Stec, 2020 


\title{
Creative Transformations: the Campus Paradigm \\ Kreatívne transformácie: paradigma kampusu
}

\author{
Peter Stec
}

V okolí európskych metropol sú rozlahlé lány transformované na výskumné centrá, odkazujúce na paradigmu akademických kampusov.

V každom historickom období, s jemu vlastnými výrobnými prostriedkami, boli procesy a priestory produkcie odlišne organizované. Je súčasná vzdelanostná ekonomika obdobím konca priestorovej diferenciácie, kedy je možné sa v podstate kdekolvek zapojit' do digitálnej produkcie? Alebo je možné analýzou historických a súčasných príkladov destilovat' akúsi esenciu kreatívnych priestorov 21. storočia?

V súčasnosti môžeme pozorovat' priestorovú premenu riadiacich centier najmä pri vel'kých technologických firmách. Prezentujú tendenciu transformovat’ sa z priestorov centrálnych administratívnych zón s hustou vežovou zástavbou na kreatívne kampusy, explicitne odkazujúce na typológiu akademického kampusu. Je zaujímavé sledovat', do akej miery súčasný inovatívny priemysel preberie formu a obsah tohto typicky vedecko-výskumného prostredia.

Text sleduje vývoj paradigmy univerzitného kampusu prepájaním základných priestorových ideí a ich autorov. Paralelne sleduje premenu významu pojmu kampus a blízkeho lexikálneho „pola”. Etymológie konceptov tábora (camp), promenády (mall), bulváru či dvora etymologicky dokreslujú priestorovú genézu kampusov.

Diagramy abstrahujúce základné priestorové vzṫahy rôznych urbánnych celkov a návrhov dokumentujú tento historický vývoj troma spôsobmi: plynulými topologickými transformáciami (od dvora cez nádvorie k promenáde atd'), diskrétnymi transformáciami rôznych patternov (násobenie dvorov do klastrov a pod.), ale aj konceptuálnym prenosom informácií a inšpirácie medzi autormi.

Je zaujímavé takouto formou sledovat' vývoj archetypu amerických kampusov: od nádvoria v Princetone, kde bol prvýkrát použitý pojem campus, cez podkovovité návrhy univerzít v Južnej a Severnej Karolíne po prvý Master plán campusu pre Union College sa dá načrtnút' priestorová kontinuita otvárania a predlžovania nádvoria na centrálnu promenádu. Túto tendenciu vd’aka širokej sieti kontaktov a inšpirácií destiluje Thomas Jefferson v návrhu Univerzity vo Virgínii, ktorá sa stane vzorom d’alších amerických univerzít plánovaných od 19. storočia. Jej pattern sa potom objaví napríklad aj v 20. storočí pri Johnsonovej iterácii pre kampus Univerzity svätého Tomáša v Houstone.

V Bratislave sa potenciál otvorenosti a vol'ných prepojení v heterogénnom prostredí ukázal aj pri plánovaní univerzít na dvoch pôvodne nedeterminovaných „poliach“ v Mlynskej doline a na budúcom Námestí slobody. Na ňom síce nevznikla pôvodne plánovaná univerzita, ale vplyv sútaže na vládnu štvrt' ovplyvnil priestorový obraz, ktorý umožňuje prekódovanie jeho identity na súčast' prilahlej technickej univerzity. Zámer presunút' univerzitu na hradný kopec za slovenského štátu sprevádzala architektonická sútłaž. Ocenený projekt talianskych architektov, prepojený terasovitou promenádou, mal formálne blízko priestorovej organizácii archetypu amerických kampusov - a špeciálne napríklad univerzite v Berkeley. Genealógiou ale vychádza z osovo organizovaných priestorov rímskeho EUR. Na Slovensku bol pojem campus pravdepodobne prvýkrát použitý v súvislosti s plánovaným areálom Polnohospodárskej univerzity v Nitre, hoci skôr obsahovo, pričom formálne odkazuje na kríženie Carda s Decumanom. V Mlynskej doline bol vysokoškolský areál plánovaný Dedečkom na podobnom princípe kríženia dvoch osí. Budovy katedier v meandrujúcich blokoch sú však priestorovo príbuzné štrukturalistickým klastrom, s ktorými pracovali napríklad The Architecture Collective alebo Herman Herzberger. Topologická transformácia priestorových diagramov na jednej strane umožňuje akúsi systematizáciu týchto rôznorodých projektov, otvára ale paralelne zaujímavé možnosti analýzy stretávania sa uživatelov a výmeny ich názorov vo vzt’ahu k týmto priestorom.

\section{Introduction}

Large swaths of land on the fringe of metropoles are now undergoing a transformation into a landscape of big boxes devoted to storage, logistics, or manufacture. On the other hand, close to cities, such as Paris or Moscow, strengthening support of the innovation economy has fueled the rise of research and development sites. Often simply labelled with the term "campus", they emulate the archetype of an academic setting. Is the reference just a metaphor, or does it convey a specific spatial organization?

Each epoch has evolved a formal relationship between the sites of production and the city. The centralized networks of feudalism drew agricultural production from the countryside to the 
city's specialized markets for produce, livestock, etc. The decentralized and functionally zoned city of modernity echoed the logic of the assembly line in routing its workers between functionally segregated districts. Will the knowledge economy, with its distributed digital networks, engender the end of urban differentiation, or will it impress its own spatial structure onto the newly emerging creative campuses of the 21st century? To understand these contemporary developments and their relationship to the city, the following study is a first step - analyzing the organization of academic grounds.

To trace the evolution of the campus paradigm, the analysis looks at the etymology of several concepts related to urban form (reflecting the former synonymity of form, concept, and idea). Their shifting meaning helps to understand the borrowing of certain spatial types across various urban functions and the convergence of specific instances in the campus paradigm.

These concepts establish a figurative "genome" of the campus. Their degree of relevance to specific projects allows a comparison of different instances across various periods and authors. By diagramming these concepts spatially, a certain formal "genealogy" can emerge. Yet even a simple tracing of the application of concepts, with their shifting meaning, to the urban morphology of universities can help to establish and visualize continuity and relationships in the development of the campus.

This continuity emerges through three different operations: smooth topological transformations (from the medieval manorial court through the cours d'honneur to the mall for example), discrete transformations of various patterns (multiplication of courts into clusters, etc.) and a transverse flow of information and inspiration between authors and projects.

Such a combination of elemental concepts with topologically connected diagrams is an experimental approach with several objectives. It attempts to organize projects of existing academic grounds into a multidimensional concept space; it systematically analyses archetypes of the academic campus to allow a comparison with their contemporary public and corporate analogues; it attempts to develop a generative method to extrapolate the included concepts creatively, engendering new families of innovative research clusters.

\section{The Research Landscape}

Picture representing natural inland scenery $\mathrm{XVI}$; view of such scenery XVII. ${ }^{1}$

Under economic pressure, the apparently bucolic landscape of the countryside is becoming striated, pixelated and analyzed to optimize its agricultural yield. ${ }^{2}$ In the new economic regime where data overtakes land, a new layer of fertility has been grafted over traditional cultivation. Near European metropoles, wide fields are being devoted to the emulation of another rural archetype: the academic village. Saclay next to Paris, Skolkovo near Moscow, new tech developments near Helsinki, all appropriate a collaborative academic setting in its most advanced form, the academic campus, to create collaborative research and innovation centers. Complementing universities, they aim to provide an environment for the highest achievements in European research quality.

\section{Knowledge Network}

Extended sense of "any complex, interlocking system" is from 1839 (originally in reference to transport by rivers, canals, and railways); the sense of "interconnected group of people" is from 1947. ${ }^{3}$

Data - barely physical, ubiquitous and infinite - forms the substrate of the fastest developing products and companies. Two formerly separate systems of value increasingly seem to overlap: the capitalist cycle of investment and returns on capital, previously almost independent from the academic network of ideas and citations. As a result, metropoles compete for highly educated, mobile and creative professionals. ${ }^{4}$

Until now, specific spatial arrangements emerged from each system of production: in feudal France for example, the court and the Parisian pied-a-terre referenced a feudal domain and a "terroir" in relation to the king and the capital. In turn, the appearance of the company town and of utopian community plans embodied the emerging relationships of the industrial revolution.

But are we now experiencing an end to differentiation, where almost any space seems likely to generate the mostly digital products of the knowledge economy, ${ }^{6}$ or do some spatial configurations perform better than others? Can an essence of 21st century space be distilled from the tendencies appearing in newly emerging creative clusters? 


\section{Headquarters}

"Residence of a military commander", 1640s, from head (adj.) + quarters. ${ }^{7}$

The increasing spatial distancing of command and control centers from industrial parks contributed to the rise of global metropoles. There, surprisingly, a seemingly irreplaceable demand for spatial proximity resulted in the emergence of the CBD and its main constituent: the corporate headquarters. ${ }^{8}$

This nerve center of supranational organizations reached its culmination in the typology of the office tower before the technological developments allowed its dissolution in the suburban landscape. Its transformation from a dense, hierarchical, one-dimensional verticality of office towers to a two-dimensional, interconnected landscape may have been fueled by the need to maximize serendipitous encounters expected to accelerate the innovative processes. ${ }^{9}$

\section{Campus}

College or university grounds. XVIII (first at Princeton, New Jersey). - L. campus field. ${ }^{10}$

Increasingly, contemporary spaces of production reference an idea, a web of social relationships and work modes, a spatial image borrowed from academia, where it emerged over 250 years ago: the campus is the new headquarters. Is the current ubiquity in using the term to denote contemporary technological and administrative workplaces a mere metaphor, a formal appropriation, or a fully functional transplant of the engine of academia into the body of business?

To trace the development of the campus idea, the evolution of the concept should be followed in parallel to the transformation of its form (understood spatially but formerly synonymous with idea itself).

This investigation has to untangle parallel transformations in the symbolic systems of language and geometry. These have separate types of inscriptions that each drift differently over time.

The strands of shifting meaning uncovered by the etymology of campus and related terms (camp, cluster, field, ground, or mall), all relate to geometric transformations that came to define the spatial image of higher education.

The word campus, meaning academic grounds, appeared for the first time at Princeton University in 1774, to denote the configuration of academic buildings arranged around an informal field, campus in Latin. Its meaning gradually shifted to denote the entire university by metonymy, unlike the formerly equivalent terms of yard, field, court, etc. ${ }^{11}$

\section{Camp}

Place where troops are lodged in tents, etc.; temporary quarters. XVI. L. campus level field, place for games and military exercises, field of battle. ${ }^{12}$

Camp also relates to campo, the root of the (originally military) camp, and of campaign. It is temporary, ephemeral, its duration more relevant than its location in space. Its sudden appearance or disappearance connotes conflict, natural disasters, displacement and marginality. Its spatial organization may be Cartesian and extremely rigid, but it is often informal, radial, concentric or multifocal. It is adaptive, highly responsive to its natural context and topography.

\section{Phylogeny of Concepts and Forms}

These few etymologies in the lexical field related to "campus" necessarily provide only limited understanding about the evolution of the spatial concepts, especially compared with the minute geometrical adaptations of physical planning.

By tracing the transformation of many words at the same time, linguistics can infer an entire phylogeny of language development, powerful enough for example to trace the geographic origins of our Indo-European language family. ${ }^{13}$

Since architecture, with its symbolic system, can be considered a form of language, a systematic tracing of its elemental transformations could provide an interesting and unexpected insight not only into the evolution of specific projects but mainly into their co-evolution in developing common archetypal solutions.

Additionally, the linguistic parallel can explain geometric similarities between projects across considerably different sites and programs, similarly to how the structure of spoken languages is constrained primarily in its form (cultural lineage), rather than its content (information transmitted). ${ }^{14}$ 


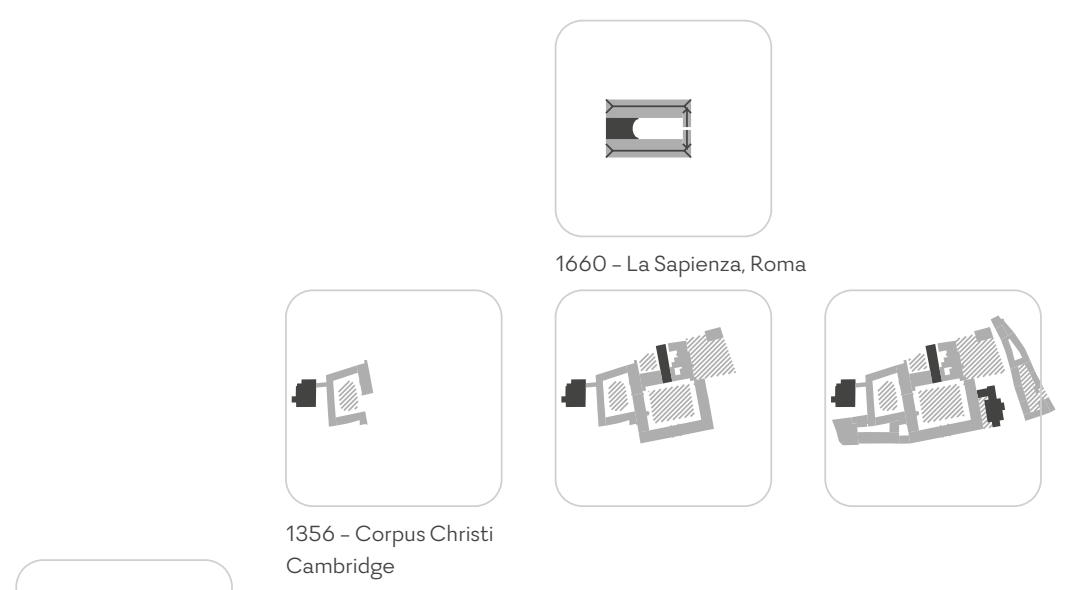

THE EUROPEAN TRADITION OF COURTS AND CLOISTERS

EURÓPSKA TRADÍCIA DVOROV A KRÍŽOVÝCH CHODIEB

Author Autor: Peter Stec, 2020

\section{Campo Marzio}

In antique Rome, Campo Marzio, the Field of Mars, used to be a site outside the city walls devoted to military training and gradually appropriated for pleasure and spectacle during the empire. ${ }^{15}$ Its informal, unstructured landscape became the site of a fictional parallel history by Giovanni Battista Piranesi. In his etchings, a seed of the modern sensibility appears in plates where the barely differentiated Campo Marzio with its remnants of ruined stadia and walls is surrounded by marble fragments engraved with partial plans of antique edifices simplified to the level of the icon. These fragments, a "formless heap" ${ }_{16}$ point toward a combinatorial system, a game of relationships between marble figures on a tablet ground, proposing a project of infinite variations, a process without ending where the parts do not predefine the whole. ${ }^{17}$

The site, densely built at the time of the engravings, is represented as a Tabula Rasa, an emptiness laden with the potential of future events.

\section{Cloister}

Enclosure, close XIII; convent; covered walk, esp. round a court XIV..$^{19}$

The origin of early universities in monasteries and monastic schools (scholae monasticae) appears in the typical courtyards surrounded by cloisters (claustra), partially in the dense urban context of Bologna and clearly in Oxford and Cambridge. Claustra shares the same Latin root of cloistrum, meaning enclosed, with the monastery. Its closed-off void, hortus conclusus, acted as a reference to the Garden of Paradise. ${ }^{20}$ Shedding the cloistered tradition, an airier collegiate environment materializes in the United States through the form of freestanding school and dormitory buildings, often organized around courtyards.

\section{Mall}

Tracing the etymology of the mall in parallel to the evolution of the spatial pattern it references, its origin emerges in a forgotten game, long fossilized in the fabric of cities and universities. Pallamaglio was played in Naples with a small ball (palla) hit by a mallet (maglio). It spread through France (paille-maille) to England (pall-mall), where it became a precursor of cricket. This urban form of billiards required long and even linear spaces. Despite the demise of the game, it remains embedded in some names, such as the street Pall Mall in London. ${ }^{21}$

Simplified to "mall" in the sense of "promenade", the term shifted to designate various urban configurations with the common topology of a linear public space anchoring various elements into an urban whole. Examples include both the National Mall - a public esplanade connecting galleries and monuments in Washington, and the Mall of America, or generically, shopping centers where a semi-private sheltered space connects various shops.

This pattern of spatial organization emerged as a common trait in the phylogeny of quickly developing American university grounds around the time of planning Washington, D. C. In cities, the mall topology appeared opportunistically and may have been difficult to preserve due to the chaotic pressures of plot manipulations, owners, intentions, economy etc. However, its persistence in university planning can be explained by the comprehensive process of development accounting 
DISCRETE TRANSFORMATIONS AROUND COURTYARDS AT THE ORIGIN OF THE HARVARD AND YALE CAMPUSES

NESPOJITÉ TRANSFORMÁCIE KOTVENÉ DVORMI: KAMPUSY HARVARDU A YALE

Author Autor: Peter Stec, 2020
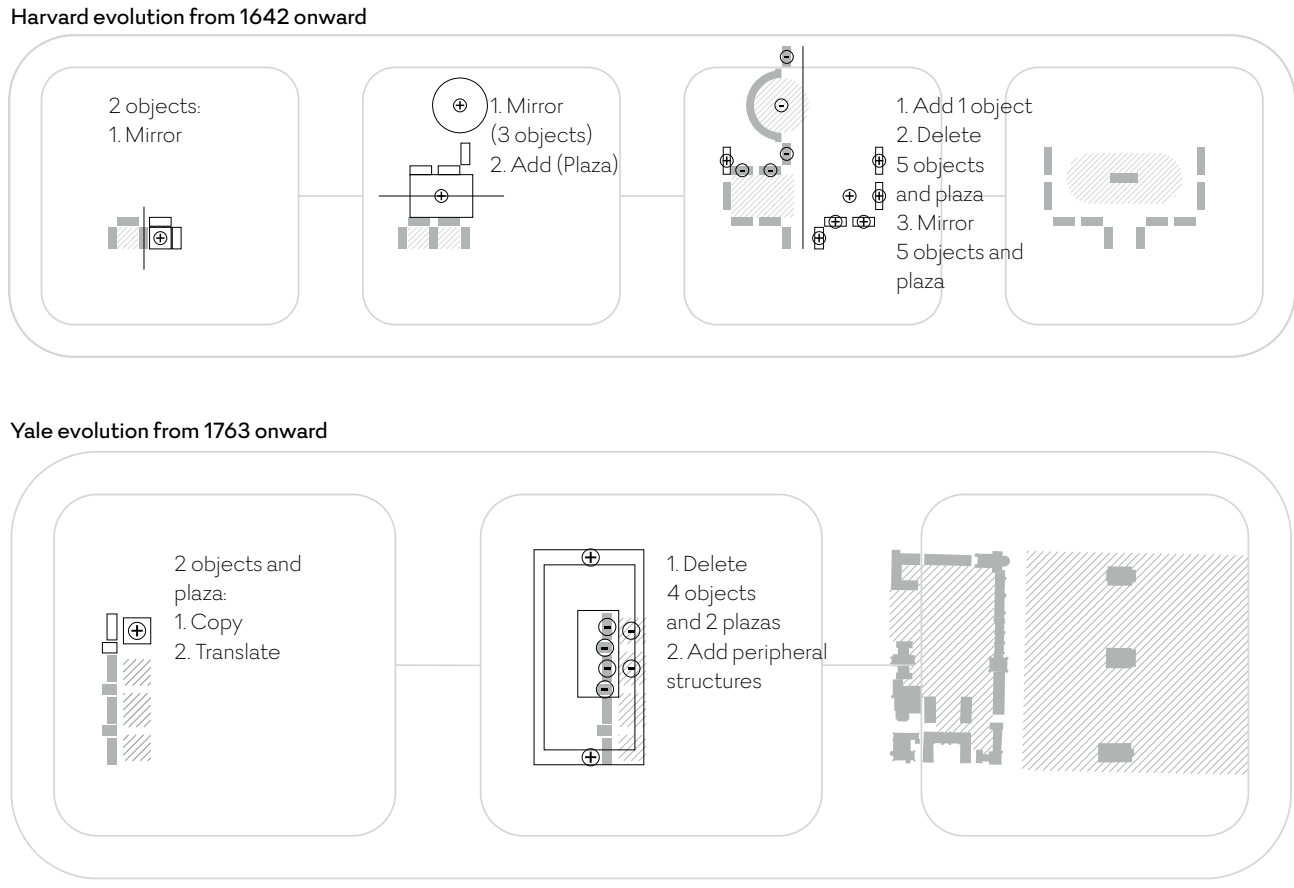

for historical and contemporary precedents. Spatial patterns can thus persist and propagate between designers and projects as a cultural legacy surpassing merely pragmatic affinities.

\section{Boulevard > Mall}

Broad tree-lined walk. XVIII. - G. bollwerk bulwark; orig. applied to a promenade laid out on the horizontal portion of a rampart in a demolished fortification. ${ }^{22}$

Two constituent ideas - the boulevard and the court - demonstrate French influence in the phylogeny of American campus planning. In the urban plan of Washington prepared by the engineer Pierre Charles l'Enfant, the grand boulevard leading from the Congress was widened to become the National Mall, a transformation closely followed by Thomas Jefferson as one of the lineages he later incorporated in his proposal for the University of Virginia.

\section{Court > Mall}

(Place of residence of) royal household and retinue; assembly held by a sovereign XII; assembly of judges, etc.; place of such assembly; enclosed area, yard XIII. ${ }^{23}$

A transformation of the court, later developed further in campus planning, occurs in the Baroque period. The "cours d'honneur" opens the medieval courtyard to the outside. The development was perhaps presaged by the Palladian "barchette" - service buildings connecting the Palladian villa to its surrounding agricultural landscape. This transformation, opening up the court, will permit an indefinite expansion of both parallel wings delimiting a linear void. An early seed emerged in the founding documents for the University of North Carolina in 1795. Its plan related to the axial spaces of colonial Williamsburg, such as the College of William and Mary or the Governor's Palace with its adjacent Palace Green. Princeton's Nassau hall with its Front Campus is another presumed influence.

In what is considered the first masterplan of an American university, Union College, by the French architect Joseph Ramée, was planned in 1813 around a court open to one side. The iterations of the evolving design show consistent topological relationships: malleably transforming the areas, they keep the structures anchored to a central building, framed by classrooms and housing.

\section{Transformations of the Mall}

After rejecting the results of an architectural competition that located all academic functions in a single building, the South Carolina College was probably the first campus to follow the spatial pattern of the mall, ${ }^{25}$ though historically subsequent to the original but abandoned intent for the University of North Carolina. 
THE NATIONAL MALL,

WASHINGTON DC, USA

NÁRODNÁ PROMENÁDA VO WASHINGTONE

Author Autor: Peter Stec, 2020

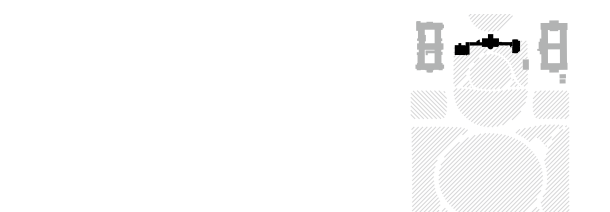

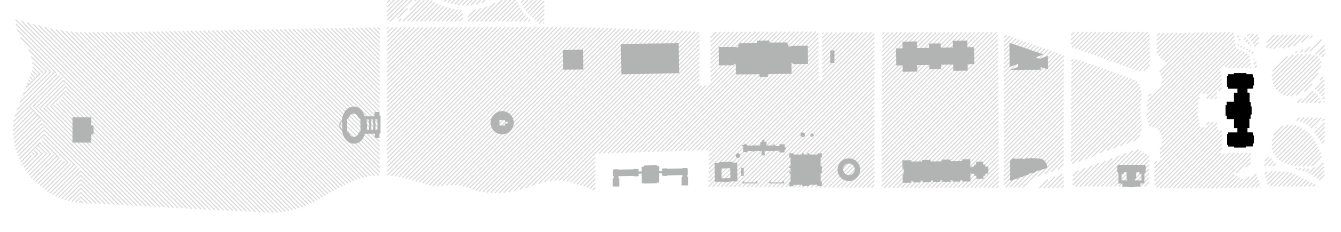
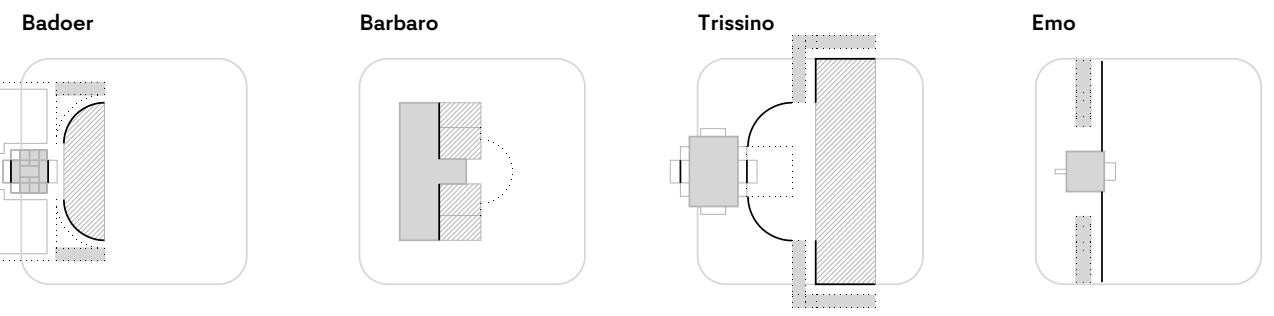

DISCRETE TRANSFORMATIONS OF PALLADIO'S VILLAS

NESPOJITÉ TRANSFORMÁCIE PALLADIOVÝCH VÍL

Author Autor: Peter Stec, 2020
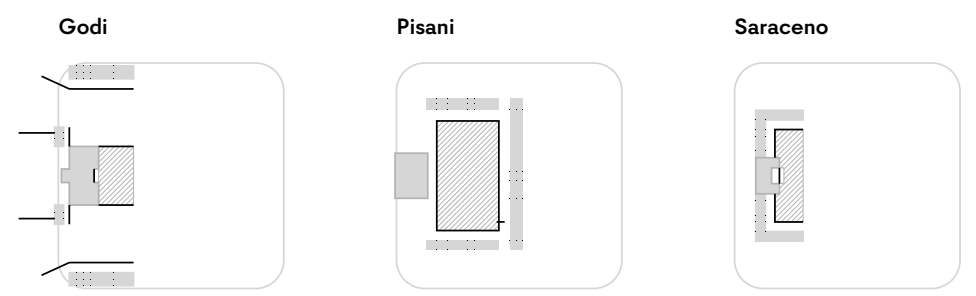

Poiana

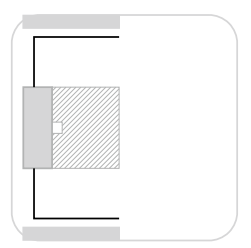

1732 - William and Mary

I
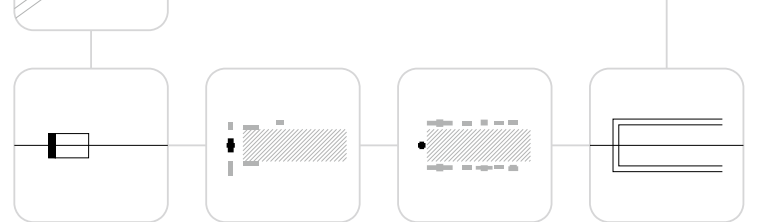

1793 - University

1793 - University of North Carolina of South Carolina

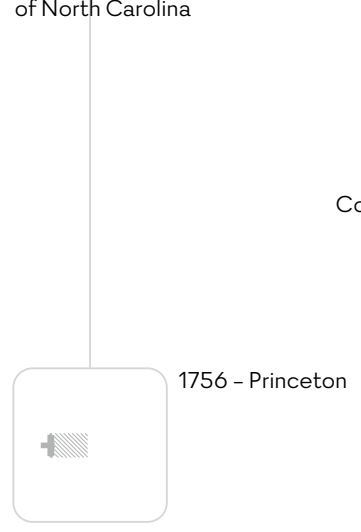

EMERGENCE OF THE CAMPUS FROM PUBLIC PRECEDENTS

VYNÁRANIE SA CAMPUSU Z PRECEDENSOV VEREJNÝCH PRIESTOROV

Author Autor: Peter Stec, 2020 

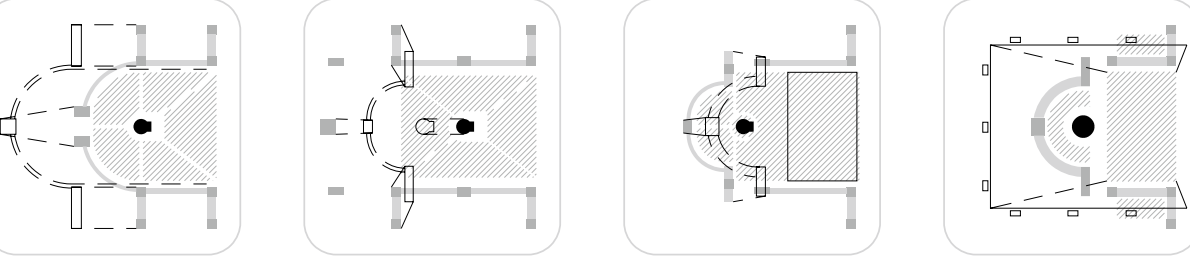

With the University of Virginia (1815), the various planning elements coalesce into a paradigmatic pattern later appropriated for many new campus developments. In this project, Thomas Jefferson demonstrated his considerable network of personal connections and influences that no doubt shaped the evolution of the design. He worked on a building addition for the College of William and Mary. As US vice-president, he oversaw a competition for essays concerning the establishment of a national university. Through personal contacts, he was aware of plans for the South Carolina College and of the configurations at Harvard and Yale. He was a frequent guest to Williamsburg and corresponded with Henri Latrobe, author of plans for a national university. Above all, he had a vision for a collegiate form of education situated in an "academical village", where professors would live above their classrooms, hosting students residing in adjacent wings in a familial setting. ${ }^{26}$

Only after a period of latency did the influence of the proposed spatial pattern become apparent in new proposals for the Universities of Minnesota, Berkeley, etc. In the 2oth century, the propagation of this spatial pattern became blurred with the advance of modernism and its incessant drive towards spatial innovation and heroic nonconformism. Nonetheless, for example at IIT in Chicago, an axial organization emerges again. Symmetrically positioned buildings define an emerging central public space, reflecting Mies van der Rohe's classicist origins.

Later, Philip Johnson, his former collaborator, recomposed the archetypal Virginia campus at the University of St. Thomas in Houston, connecting together several pavilions reminiscent of IIT's steel framing into an urban ensemble spanning several urban blocks and enclosing a modernist mall defined by slender steel colonnades.

\section{Urban Links}

The role of knowledge and its distribution in various historical periods helps to understand patterns of internal campus organization and external relationships to the city.

The monastic schools inherited from the originating built form of the monastery a spatial pattern of multiple layers of separation from the surrounding city and the world in general: the cloister, protecting the hortus conclusus representing the garden of Eden; the external walls rendering the monastery a small fortress; finally, its customary location a certain distance beyond the walls of the city and its "temptations."

And so, while the historic premises of Princeton University at Nassau Hall, where the term was originally used, originated in a different and distinctly American tradition of freestanding college buildings, legible already at Harvard and Yale, the developing campus created a clear-cut opposition between academic and urban grounds, separated by Nassau Street. For its Graduate College, the traditional argument of cloistered study prevailed by gathering graduate students in a location separated from both the city and the main campus.

The similarity between the colleges of Cambridge University and the monasteries attests not only to a common origin, but to a continuity of program, having to accommodate (protect, focus...) in both cases groups of single men devoted to religious and scholarly pursuits. ${ }^{27} \mathrm{Howev}^{-}$ er, the closed quad begins to open during the Renaissance starting with the Gonville and Caius College in $1557 .^{28}$

The town of Cambridge is among the examples chosen by Christopher Alexander in his essay "A City Is Not a Tree" to illustrate blurred boundaries and overlaps between various social groups and spaces (students, professors, townspeople, pubs, halls etc.) and in general, between the 


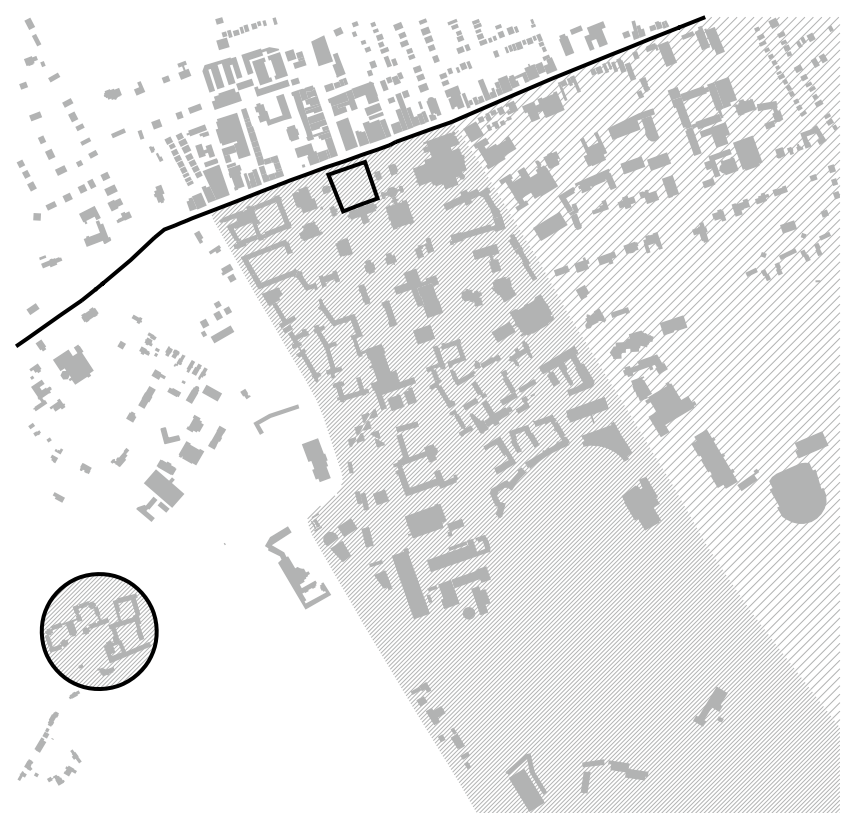

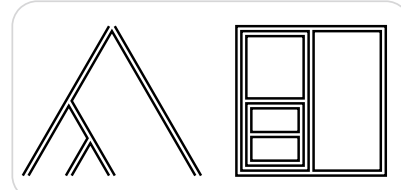

THE PRINCETON CAMPUS, WITH
THE GRADUATE COLLEGE AND THE ORIGINAL CAMPUS AREA IN FRONT OF NASSAU HALL

KAMPUS UNIVERZITY

$\checkmark$ PRINCETONE, POSTGRADUÁLNE

KOLÉGIUM A PÔVODNÝ „CAMPUS"

PRED NASSAU HALL

Source Zdroj: Peter Stec, 2020, based on openstreetmap.org.

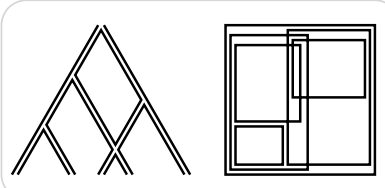

TREE AND SEMI-LATTICE NETWORKS: STRICT HIERARCHY AND OVERLAP

STROMOVÉ A PRELÍNAJÚCE SA GRAFY: STRIKTNÁ HIERARCHIA A PRIENIKY

Author Autor: Peter Stec, 2020

university and the town. He denotes these overlapping sets as "systems", but their definition is left loose and allows the creation of almost arbitrary system boundaries to trace a graph of interactions in between. Thus, Alexander views the social systems of Cambridge as a "semi-lattice" graph, with a non-hierarchical overlap opposed to hierarchical "tree" graphs:

"At certain points, Trinity Street is physically almost indistinguishable from Trinity College. One pedestrian crossover in the street is literally part of the college. The buildings on the street, though they contain stores and coffee shops and banks at ground level, contain undergraduates' rooms in their upper stories. In many cases the actual fabric of the street buildings melts into the fabric of the old college buildings so that one cannot be altered without the other." ${ }^{29}$

Such a "grown" town contrasts with the hierarchical "tree" diagrams of modernist spatial planning, such as the Communitas by Paul and Percival Goodman, where the city expands in concentric rings from the commercial center through a university ring to residential zones onwards..$^{\circ \circ}$

These observations can be further developed by analyzing the type of flows between the nodes of systems in various periods.

Rather than different historical means of production (land, capital, data), the routing of products and people in each era can explain various paradigms for the emerging urban networks.

The agricultural products of feudalism converge in a simple centralized network to the markets of regional cities and the countryside is referenced in a city like Paris by the products of its terroirs being sold in the urban pied-à-terres of French aristocracy. The modernist city, in Alexander's caricature but often in orthodox CIAM urban planning as well, consists of several networks or systems, zoned to avoid overlap. Hence factories are located in exclusively manufacturing districts and follow assembly-line layouts with clear input, production and output. And the modernist city itself follows a similar paradigm, where the workers themselves circulate between segregated housing, manufacturing, recreation, and commercial districts.

In this paradigm, education can form a clearly separated district as well. The IIT in Chicago for example, originally planning to move out of its location on Chicago's Near South Side, radically occupies its available land when unable to do so and starts a new development pattern in the area. It razes the entire 40 hectares available, striates the obtained tabula rasa and extrudes volumes out of this spatial continuum. In complete opposition to the scale of the preexisting and surrounding urban fabric, it generates an educational island with a completely distinct and homogenous quality. It seeds the development of Chicago's superblock systems, clearly legible on the Near South Side with the subsequent redevelopment by the New York Insurance Company and others. These systems, clearly distinct carpets of functions starting with education, graft a decentralized patchwork 
NETWORK TYPES: CENTRAL, DECENTRALIZED BUT HIERARCHICAL, DISTRIBUTED.

TYPY SIETÍ: CENTRALIZOVANÉ, DECENTRALIZOVANÉ NO HIERARCHICKÉ, DISTRIBUOVANÉ.

Author Autor: Peter Stec, 2020, urban application of diagrams in: BARAN, Paul, 1962. On Distributed Communications Networks [online]. Santa Monica: RAND Corporation, 1962, p. 4. [Accessed 8 June 2020]. Available at: https://rand. org/pubs/papers/P2626.html.
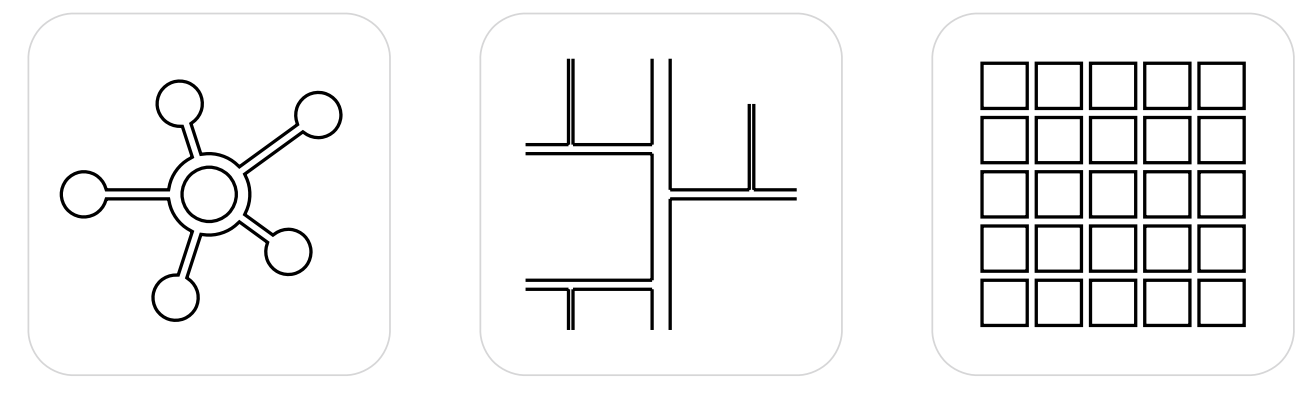

of large areas onto Chicago's distributed grid and approach modern urbanism's orthodoxy of monofunctional zoning by shifting the scale of the urban grid.

“...[R]ather than forming just a set of innovative buildings, the campus forms an integral component of a larger, more complex and multifarious field. Mies's plan for IIT initiated a new form of modern urbanism that represents an epitome of the Chicago superblock that is at once figural and abstract, figure and ground. An inner-city landfill of green carpet, the campus offers an example of how the superblock reconfigures the urban grid in order to figure space. Even fans of the campus describe it as an autonomous island that disregards its physical and social context." ${ }^{11}$

St. Thomas in Houston by Philip Johnson emulates the construction details of IIT. On an urban level, however, it is a hybrid project combining the distributed grid network of surrounding Houston, the internal hierarchical mall organization similar in size to Virginia, with the structured elegance and materiality of IIT. The square urban blocks alternate as figure and ground with the mall reaching across them - lightweight, permeable, but continuous. The university forms a carefully inserted chain linking it to the city. The colonnades encircling the St. Thomas mall provide a horizontal public circulation and layering that binds the various volumes of classrooms, offices and vertical communications into a varied unity. Although formulated on two levels, the connecting topology of the colonnades shows a graph very similar to the mall at the University of Virginia. The three urban blocks linked in Houston correspond to the three landscaped terraces linked at UVA. And the connection of separate buildings directly echoes UVA., with its colonnades linking student quarters to pavilions with classrooms at ground level and professors' residences above.

The mall, originally a linear space for play, has been adopted independently through the city and the university to connect loosely standing edifices through a figural void, rather than just through an abstract link. It evolved into a complex connective topology that replaced the linear connection by a three-dimensional loop. Originally autonomous in the case of the University of Virginia, it became a connective link bridging the university/city divide at St. Thomas for example.

But while on the urban level, the University of Virginia started as an academic village disconnected from the nearby town of Charlottesville, ${ }^{32}$ its internal organization clearly articulates the spatial connections between teaching and learning, revealing education hierarchies of a specific historical period.

\section{The 'Mars Fields' of Bratislava}

Two "fields" in Bratislava bore a heterogeneous, heterotopic ${ }^{33}$ set of qualities akin to Campo Mar$\mathrm{zio}^{34}$, and both had to play important roles in the establishment of university campuses in the city.

Before the dissolution of Austria-Hungary, the Empress Elizabeth University was established in the city in 1912, with the intention of reinforcing the waning influence of this former capital of the dual monarchy. A study was conducted a year later, and a competition followed in 1916, both situated mainly on the former palatial gardens of the northern suburbs. ${ }^{35}$ The archbishop's palace acted as an urban artifact ${ }^{36}$ in strongly conditioning and charging its surroundings, forcing all subsequent projects into a formal reaction. Though later abandoned, the intent to establish a campus would later re-emerge on the site of the former archbishop's gardens, now Freedom Square.

Then, in the early 1930s, a competition for the new "University City" was held on what was then the urban fringe, a sparsely settled location found below Castle Hill opposite the Old City called the "Mill Valley" (Mlynská dolina). A cemetery, mills, and a few gardens were some of the 


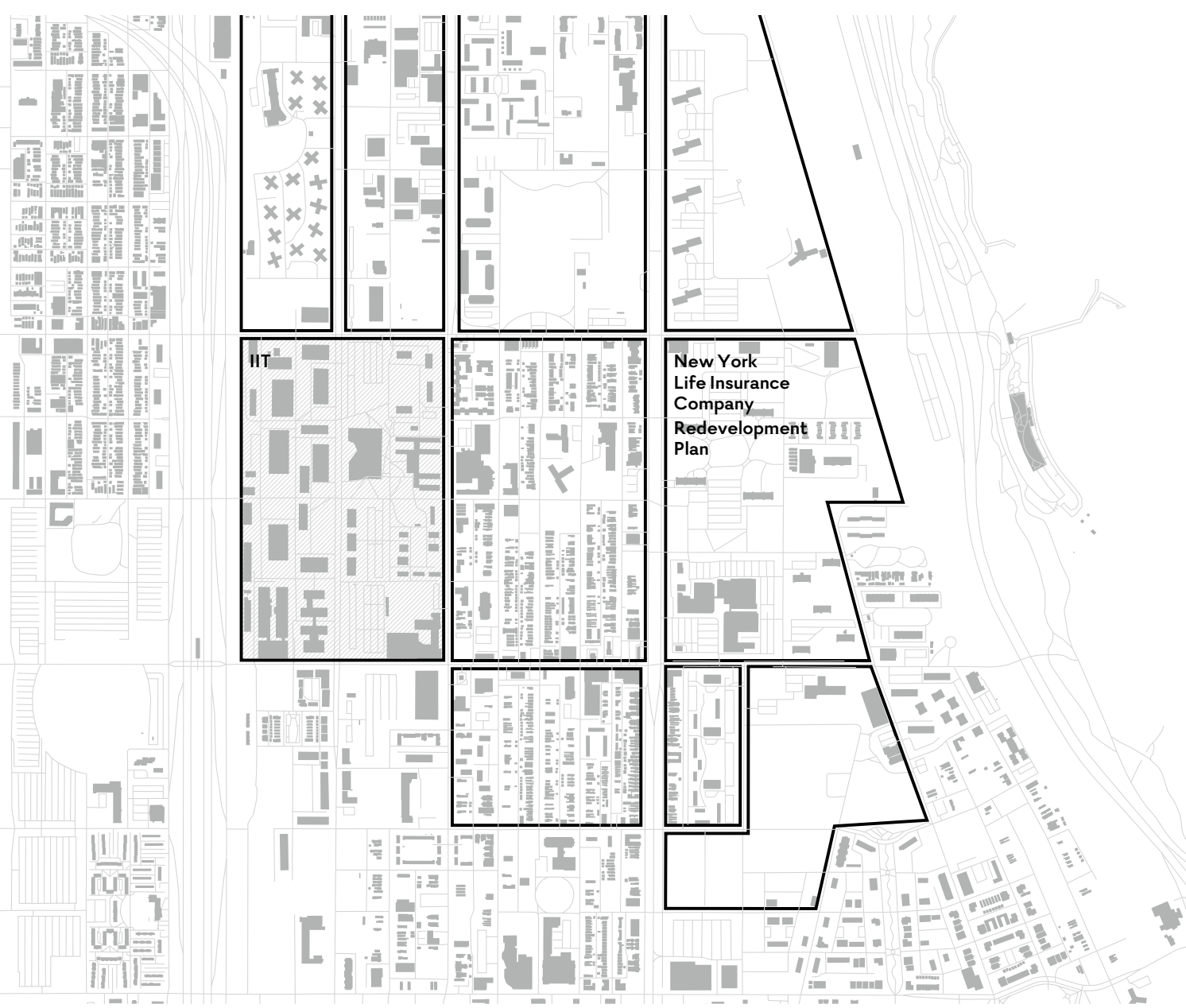

NEAR SOUTH SIDE SUPERBLOCKS

CHICAGSKÉ SUPERBLOKY VO ŠTVRTI NEAR SOUTH SIDE

Author Autor: Peter Stec, 2020 based on openstreetmap.org and MCKINLAY, JOHN, 1950. South Side Board Redevelopment Plan for the Near South Side. Redevelopment Project No. 1: A Second Report. The New York Life Insurance Company Redevelopment Plan, p. 8. land uses present. ${ }^{37}$ The Lafranconi student housing by Klement Šilinger had just been completed nearby and seeded the educational patterns in the area. ${ }^{38}$

With the advent of war, the elaborate plans were never implemented. But through a strange persistence ${ }^{39}$ of intentions, the potential of both sites to become a campus resurrected after World War II.

\section{Freedom Square}

From Fürstenallee, the linear Princes' Alley colloquially called "Firšnál”, the site of military drills, fairs and circus attractions was also nicknamed "Sahara" for its increasingly barren impression. After the 1948 putsch, Freedom Square (Námestie slobody) was appropriately renamed to Gottwald Sq. and later anchored by a stern sculpture of the first socialist president and his followers. Its former name reappeared with the collapse of communism..$^{\circ}$

On a square quickly becoming a vortex of political power, these naming iterations trace a process of ideological shifts expressed through architectural intentions that remained nevertheless often unbuilt. Once Bratislava became one of the regional centers in newly created Czechoslovakia, the need for administrators and office space became urgent.

In 1930, the architectural competition for the Land Office showcased intentions to turn the square into Slovakia's government quarter. Two of the rewarded projects proposed functionalist "document factories", set to redefine the spatial orientation of the square by enclosing respectively the flanks or the front of a piazza created in front of the Archbishop's palace. Both introduced bold horizontal volumes of copiously lit offices acting as enclosures of public space.

The next step in defining the area occurred with another competition for government offices in 1942. At that time, Slovakia was nominally yet fictitiously independent. The previous plans of a university campus on the square were rejected, with the decision to establish a university next to the ruins of the castle instead. 


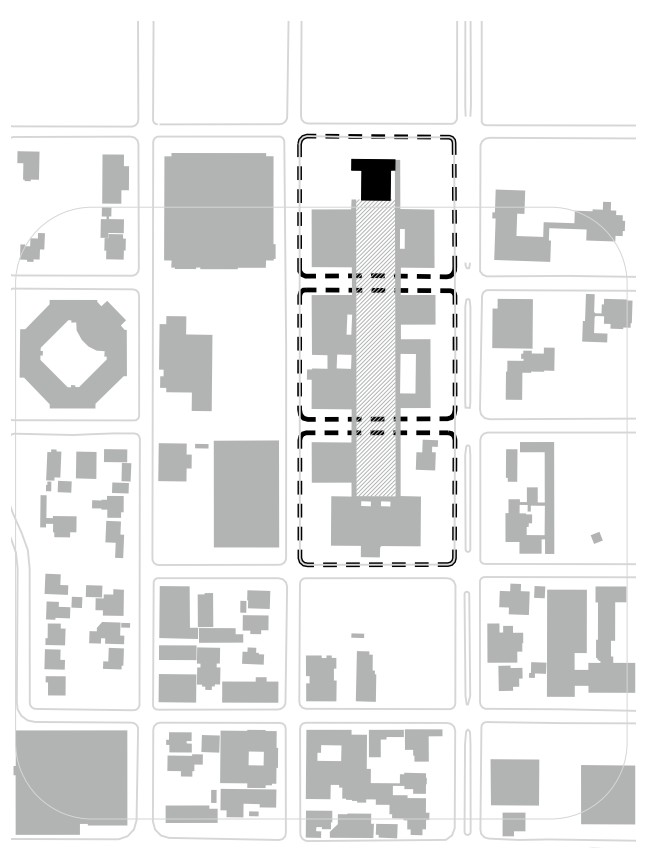

ST. THOMAS NETWORK

URBÁNNA SIEŤ UNIVERZITY

SV. TOMÁŠA

Source Zdroj: Peter Stec, 2020, based on openstreetmap.org
MAP OF EXISTING AND INTENDED CAMPUS AREAS

MAPA EXISTUJÚCICH

A POTENCIÁLNYCH KREATIVNNYCH CAMPUSOV

Source Zdroj: Peter Stec, 2020, based on openstreetmap.org

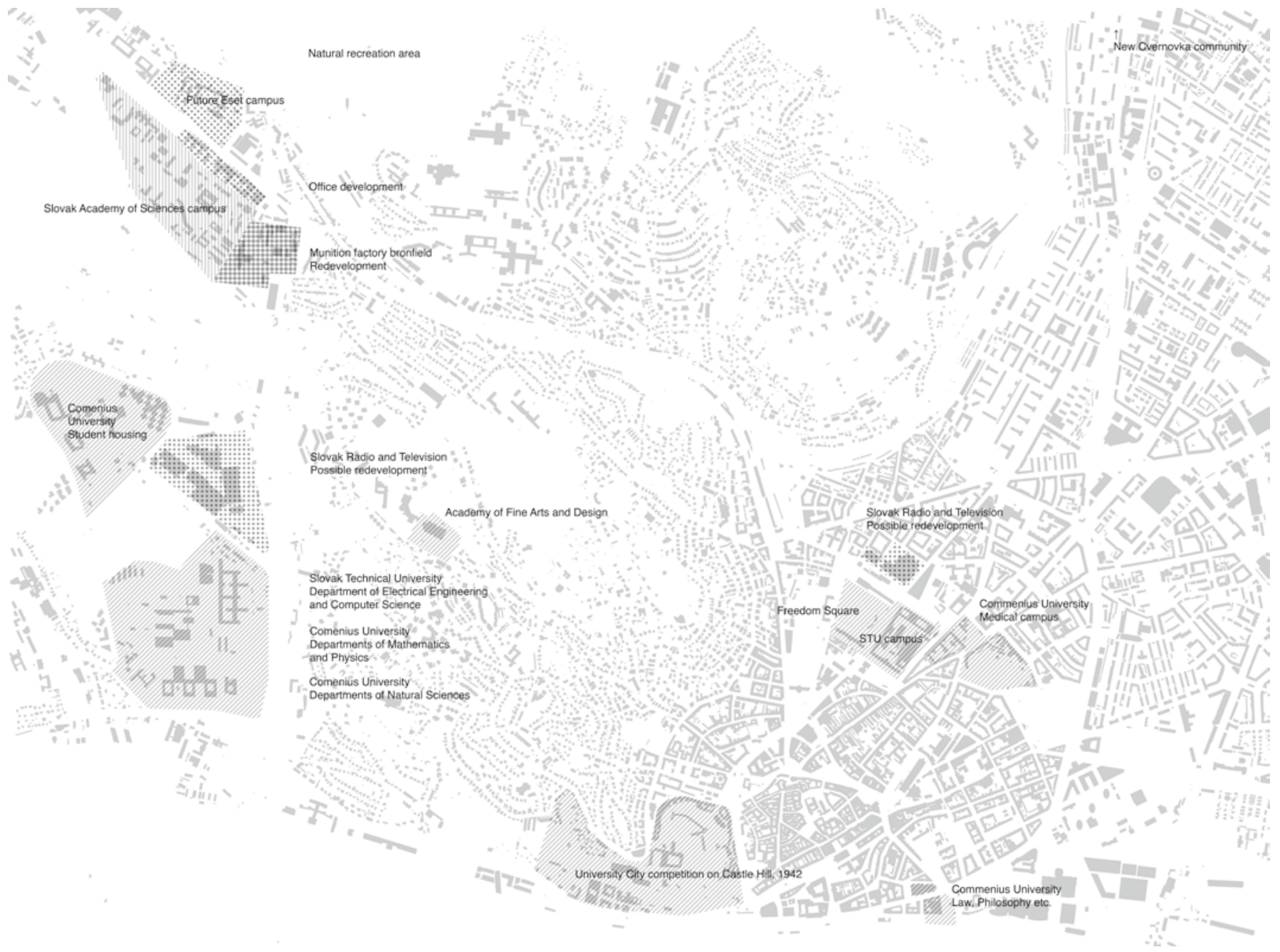


1943-COMPETITION FOR GOWERNMENTAL DISTRICT, J. GOČÁR AND A. LIBERA WITH E. LA PADULA

1943 - SÚŤAŽ NA VLÁDNU ŠTVRŤ, J. GOČÁR

A A. LIBERA S E. LA PADULA
1948 - SLOVAK TECHNICAL UNIVERSITY CAMPUS E. BELLUŠ AND CURRENT STATE

1948 - SVŠT KAMPUS E. BELLUŠ A SÚČASNÝ STAV
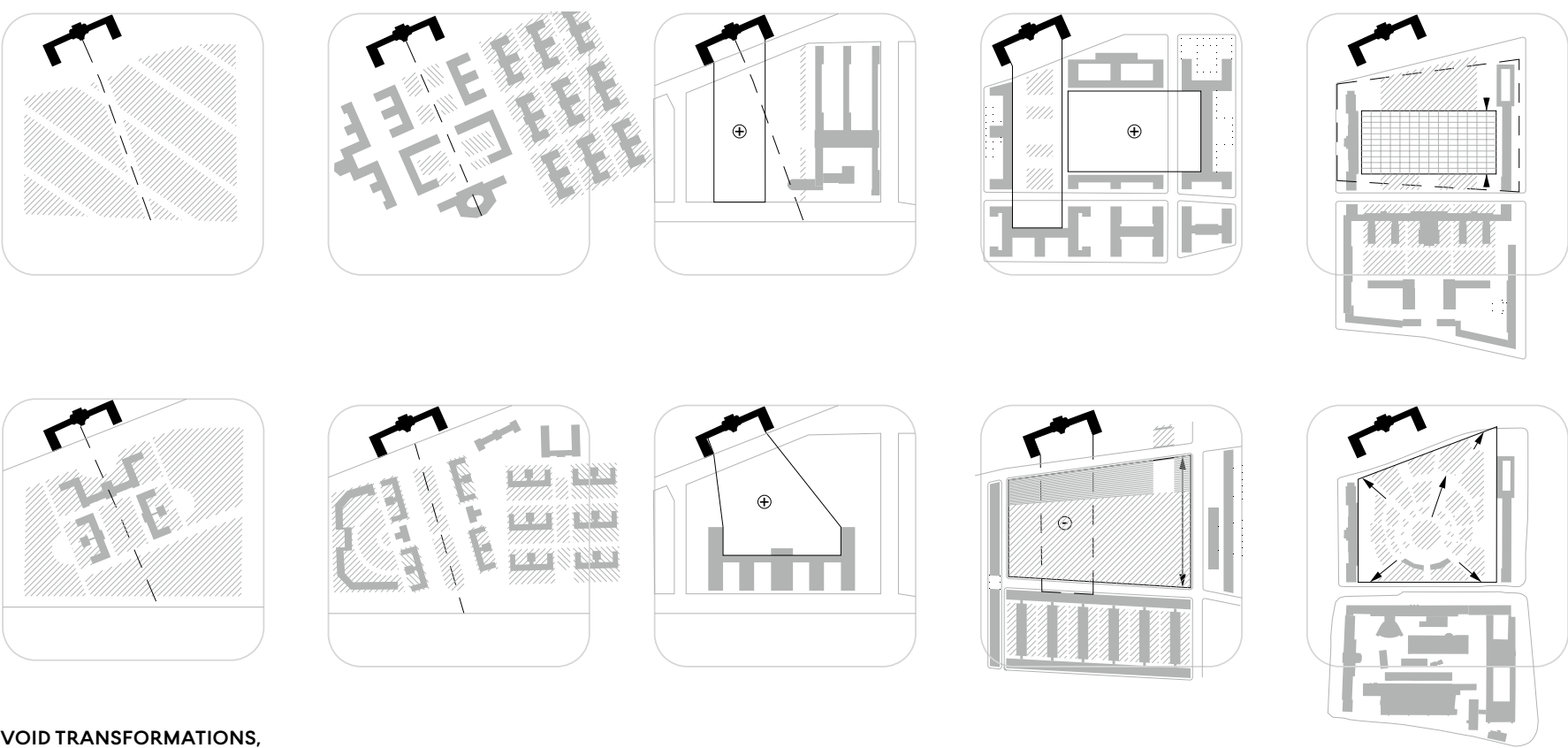

VOID TRANSFORMATIONS, FREEDOM SQUARE

TRANSFORMÁCIE PRÁZDNA, NÁMESTIE SLOBODY

Author Autor: Peter Stec, 2020

The winning project by Josef Gočár splits the area into two: the smaller void is book-ended by the archbishop's palace and the new office wings, while a larger one offers a perpendicular counterpoint introducing an oscillating reading of spatial hierarchies. The public spaces are reduced by pragmatically situating office buildings inside the area's perimeter.

In retrospect, the unified space of Adalberto Libera and Ernesto La Padula, the design ranked second (ex-aeco with a Viennese team), proved to exert a stronger formal influence than the winning project's double piazza. ${ }^{41}$ This vast area was intended for the staging military drills in a symbolic demonstration of the oppressive Hlinka Guard (a function later reclaimed by the Peoples' Militias under Communist rule).

After WWII, the Slovak Technical University received approval for its long-standing intention to develop the square into a university quarter. Emil Belluš prepared a master plan enclosing the remaining two edges of the plaza, creating a spatial correspondence between the post building and the new Pavilion of the Theoretical Institutes that he designed on the opposite edge, built after the 1948 communist putsch by (supposedly) voluntary brigades of students and workers.

Further development of the Southeastern edge from the 6os onwards created one of the crucial academic centers in the city. It can be assumed that merely the neglect of education and its urban manifestations prevented the organic appropriation of the square into a core of the tech campus. Recent competition results conserve the strange gradation of landscaping towards the demolished monument of Gottwald o Co., ${ }^{42}$ instead of supporting programs catalyzing urban and academic creativity, like a (below-ground) library for example.

The open-ended transformation of the square from a garden towards the seed of a campus for the Slovak Technical University demonstrates the persistence of spatial visions that take precedence over programmatic requirements, gradually crystalizing in an urban form despite fluctuating programs. Cultural genealogy triumphs over disparate functional demands. 


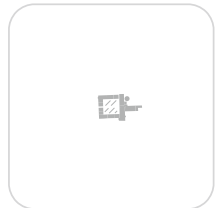

1249

University College

Oxford

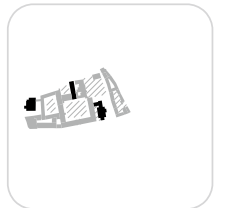

1356

Corpus Christi

Cambridge

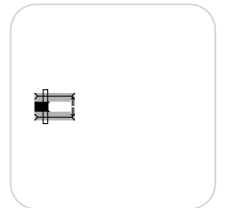

1660

La Sapienza

Roma

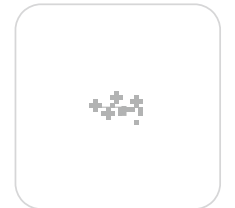

1957

TAC

Collier's Magazine

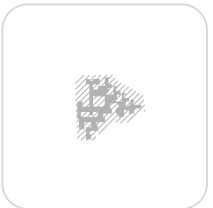

1960

Orpanage

Amsterdam

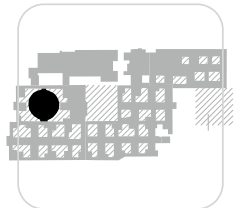

1963

Campus Dahlem

Freie Universität Berlin

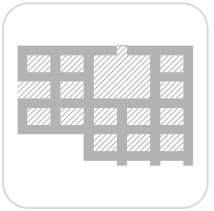

1964

Campus
CLUSTERS

KLASTRE

Author Autor: Peter Stec, 2020

\section{University City, Castle Hill}

The competition for the relocated University City offered a site composed of two vastly distinct areas that both proved to be highly symbolic - the Castle Hill and the Jewish quarter. The hill was dominated by the burned-down castle ruin, considered by all participants beyond repair and needing to be replaced by new proposals. As for the demolition of existing housing to give way to shining educational buildings, it was justified at the time by their lack of upkeep. Omitted was the glaring absence of economic opportunities first of all, and the inhabitants' later fate: the competition was published in the year of Slovakia's Jewish deportations to extermination camps. ${ }^{43}$

Conveniently, the two highest-ranking teams were from the fellow Axis states of Italy and Germany. In the Roman proposal, Attilio La Padula joined his brother Ernesto, one of the authors of the haunting, "metaphysically" monumental "Square Colosseum" for the 1942 World Fair, planned to be held in Rome.

The Italian team introduced a campus organization dependent on a linear axis of terraces rising towards a central monument. While indubitably reflecting the classicist tradition present in their World Fair project, it also developed with strange consistency the genealogy of American campuses organized on a mall, rather than the European tradition of urban campuses organized around courtyards in the monastic tradition of cloisters. Oriented against the grain of the existing topography, it abolished the historic distinction between the walled medieval city and the ramparts of Castle Hill. In a typical pattern established with the university campus and emulated in any shopping mall, the ceremonial mall of the University City in Bratislava connects two major anchors at its extremities. In this case, the piazza in front of the cathedral is linked with the iconic university building replacing the castle ruin through a procedural route, with symmetrical buildings arranged along a cascade of terraces.

Never implemented, the persistent intent of locating the university on Castle Hill was resurrected in 1992, when the unfinished building of the Slovak Parliament nearby was considered for hosting the nascent Central European University. Bratislava later lost the bid to Budapest and Prague for barely trying, after canceling the Parliament option and proving unwilling to offer an alternative. ${ }^{44}$ Still, after Prague, now Budapest is poised to follow Bratislava's fate and lose the highly ranked university for similar political and ideological, or perhaps nationalist and provincial reasons to Vienna. 45

\section{Cardo / Decumanus}

North/South axis, from cardo (n.): "A hinge or hook. Used metaphorically for a variety of things on which others turn." ${ }^{46}$ East/West Axis from the street separating the 10th and 9th cohorts of a roman military camp.

Vladimír Dedeček understood his project for the Agricultural University in Nitra as a campus, though referencing complex and complementary activities, ${ }^{47}$ rather than a spatial configuration. The project's organization is based on the crossing of an open-air access path with an enclosed service path connecting individual school pavilions - an intersection referencing the Cardo/Decumanus central to Roman colonial cities. ${ }^{48}$ 


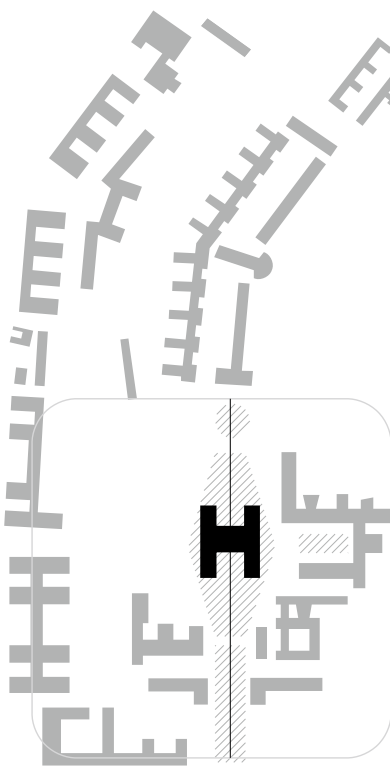

1942 - CASTLE HILL, COMPETITION ENTRY E. AND A. LA PADULA 1942 - HRADNÝ KOPEC, SÚŤAŽNÝ NÁVRHE. A A. LAPADULA

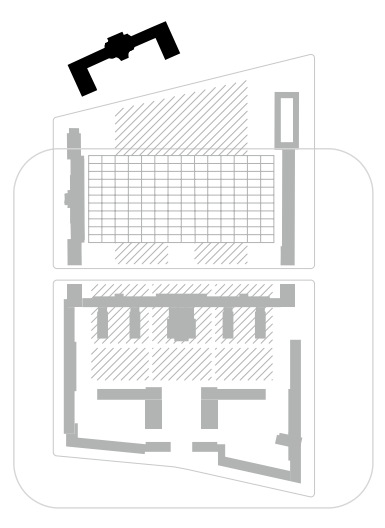

1948 - FREEDOM SQUARE

1948 - NÁMETIE SLOBODY

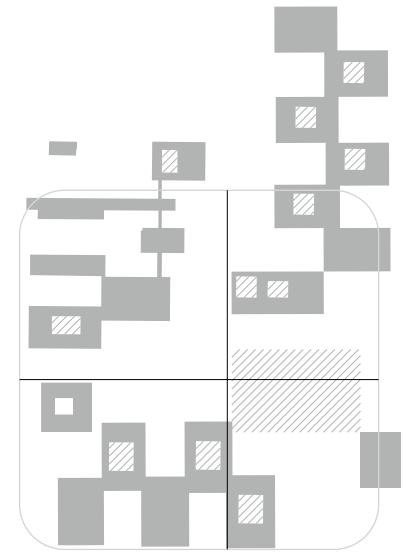

1966 - MLYNSKÁ DOLINA
COMPARISON OF THE CAMPS PROPOSALS IN BRATISAVA

POROVNANIE NÁVRHOV KAMPOV $\checkmark$ BRATISLAVE

Author Autor: Peter Stec, 2020

\section{The Valley: Science Campus}

In the 6os, four teams were invited to compete in consolidating departments of Comenius University on the heterotopic site of the Mill Valley (Mlynská Dolina) at the western fringe of the city, already considered before World War Two. The winning team, Dedeček's studio at Stavoprojekt, proposed a department massing reminiscent of the axial organization in Nitra: two covered corridors connecting slab buildings meet perpendicularly at an academic piazza, next to the library and administration objects. ${ }^{49}$ Additional pavilions for mathematics and physics are located in the academic quadrant, with sports facilities to the North. A subsequent iteration of the proposal modified some of the slab buildings into meandering blocks with internal atria.

After the 1968 Soviet occupation, shifting priorities prevented any consistent implementation of the master plan, possibly out of distrust for a massive student community. The academic piazza with the administration and rectors' offices were left out, , $^{50}$ compromising the legibility of the plan and eliminating the open meeting spaces that could provide a sense of spatial identity and community.

Located to the North, a second area in the master plan was devoted for student housing. It lay across a cemetery that was first planned to be relocated but later incorporated into the heterotopic landscape. The proposed housing adopted a checkerboard organization of atrium blocks organized into several clusters. To adapt and develop topographical features of the hilly site, the blocks are oriented to follow contour lines and have receding top floors, supporting the intended "horizontalism" of the design..$^{1}$

\section{Clusters}

Collection of things close together. OE clyster, (rare) cluster, also gappeclystre bunch of grapes, prob. f. *klut- (see CLOT). ${ }^{52}$

Dedeček oversaw many school projects in the Stavoprojekt state office. While not referencing any archetypal university master plan, he followed contemporary architectural tendencies, such as the growing modular school clusters by the Architects' Collaborative that he saw exhibited in Moscow..$^{53}$ His affinity for a structuralist cluster organization later clearly emerged in his project for the campus of Comenius University, evoking the application of structuralist theories explored at that time by van Eyck, Herzberger and others. The parallel-ground projects proposed by the Smithsons, or the math building of Berlin's Free University, provide the conceptual context of corridors with plugged-in classrooms indefinitely expanded as a field. 
MAPA S CENTRÁLNYM

A VÝCHODNÝM VÝSKUMNÝM SUPERKLASTROM

Source Zdroj: Peter Stec, 2020 based on openstreetmap.org.

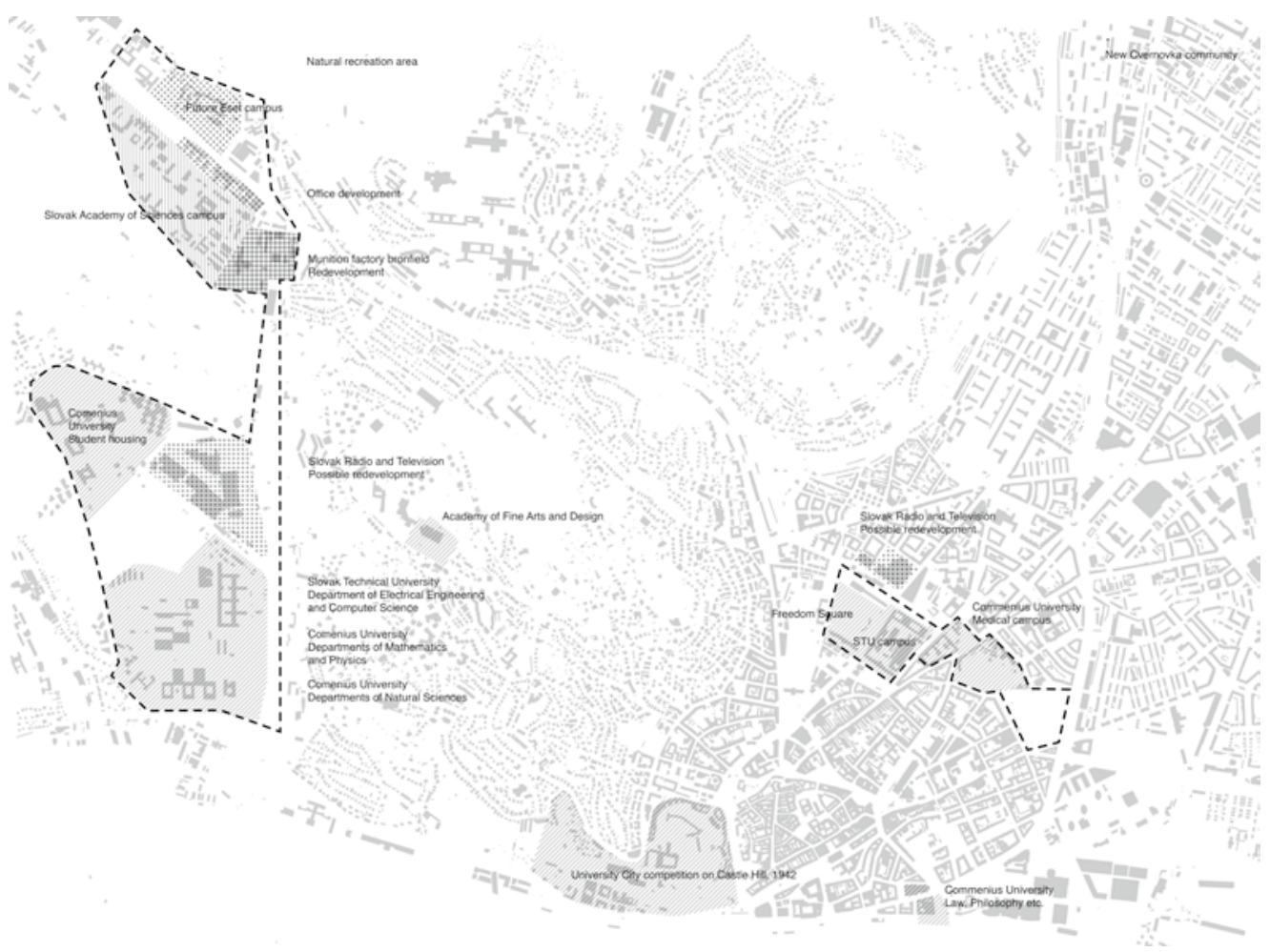

The hierarchy of voids present in the Comenius university master plan remains an unfinished proposal where only the smaller scale atria could be tested, as the major axes and communal spaces were aborted. These certainly complement the scale of communal spaces with the addition of open-air but sheltered voids. While creating an identity for both the departments and housing units, their full potential remains undeveloped due to a lack of funds and control.

Similarly, the university community has been stymied by the absence of the large-scale links legible enough to create an overall sense of identity. The modernist focus on objects, the lacking private or nonprofit initiatives, and the functional segregation between academia and housing prevents for now the establishment of an active 24-hour cycle diverse enough to generate a collegiate environment.

\section{The Valley and the Square}

In Bratislava, both the previously heterotopic, under-defined fields of the Valley and the Square were seeded by two different spatial devices, the linear crossing and the gridded piazza.

The Cardo/Decumanus crossing is at the head of the science campus development, running northward along the Valley. The University master plan added two independent but formally related clusters of education and housing on opposite ends of the existing cemetery. Additional clusters of programs situated along the valley and its highway can be considered complementary in engendering a potential innovation hub. It is currently organized linearly, hierarchically, and with little spatial overlap. The heterogeneous spatial mix includes, northwards: the Radio and TV campus; a zoo; the Slovak Academy of Sciences; the former Patrónka munition factory, a historically charged site considered for a cultural redevelopment; new offices often rented to tech companies such as Siemens etc.; finally, close to a hilly recreation site, the future research and development campus of the IT company Eset.

The striated square, appearing in 1942 with the Libera/La Padula submission and reworked in 1948 by Belluš, can be considered as the Northern ceremonial entrance to an academic quarter comprised of the technical campus, with the Slovak Radio building nearby, followed southwards by the University Hospital and the medical faculty, bookended by its formal gardens, and a cemetery. The blocks, linearly contiguous, show complementary programming and boundaries based on historic urban blocks. In contrast to the hierarchically segregated programs of the valley, the square introduces an urban campus stitched into the fabric of the surrounding city. 


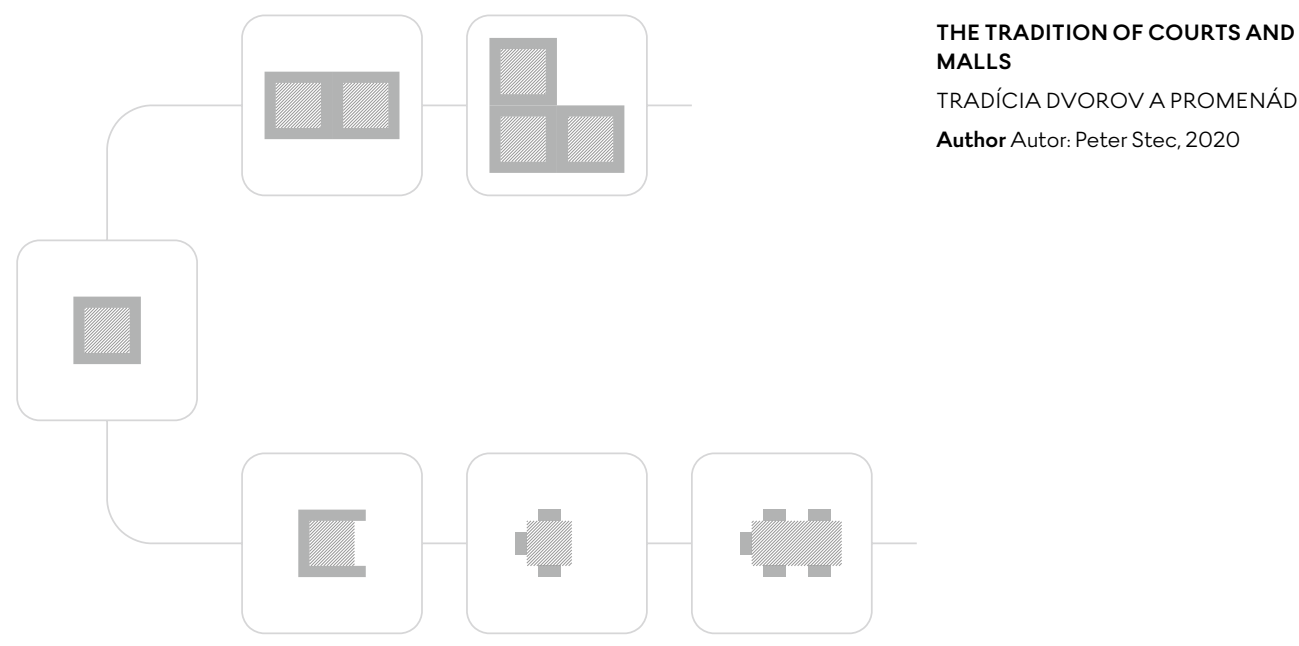

\section{Conclusion}

In campus planning, the mall is one of several spatial patterns that emerge gradually to be subsequently adjusted in several iterations. To simplify the topological transformations of its "phylogeny", one could start with the topologically enclosed space of the Roman castle, the claustrum, and later with the claustra of medieval monasteries that encloses its inner garden. In parallel to the evolution of universities from the scholae monasticae, the cloister engenders the courts organizing their spaces.

Already at Cambridge, but also in contemporary examples, the courts multiply and aggregate into earlier, opportunistically grown or later, planned Cartesian clusters.

Also, at Cambridge, the court starts opening up to initiate a development taken over in American campus planning: the loosening of the college's spatial enclosure and the extension of the void organizing adjacent academic structures.

This topological system, and the related etymology focused on academic spaces, cannot trace in detail the very complex nature of built environments and even less the ephemeral and transient nature of spatial references and inspirations. Nevertheless, it points to relationships that could be unearthed between the graph of spatial connections in a campus, and its planned or serendipitous structure of idea exchanges. In parallel, it outlines a possible structure to reference ideas in a topological form between various planners, and across different projects.

It is by adapting to the surrounding landscape and topography that the university grounds achieve a nonlinear connectivity. Landscape in the form of continuous terracing binds together the grounds of Virginia University, Berkeley or La Padula's plan for the University city and others.

This loose connectivity of disparate buildings establishes a distributed network, where knowledge is exchanged informally at the interface between the town and the university of Cambridge for example, in the Free University of Berlin mat, or across the Comenius University clusters.

The campus, Latin for "field", creates a consistent plane where gradients and orientations register to link otherwise heterogeneous constellations of buildings, first at Princeton University but increasingly in contemporary urbanism. As a concept, it seems to be replacing the "headquarters" to denote a creative center of organizations like Facebook or Google, emphasizing perhaps a serendipitous and unpredictable connectivity opposed to a hierarchical, "tree" structure.

Finally, the mall emerges as an etymology and a diagram informing various iterations of uni-

Research partially funded by the Fulbright Scholar Program and the Research Center at AFAD.

PETER STEC, M. ARCH.

PETER STEC STUDIO

Mečíková 26

84107 Bratislava

Slovakia

Peter@PeterStec.com versity planning, a void figure binding the projects internally, as a planning family, and often on an urban level as well.

These terms, applied here to study university grounds, outline a conceptual and figural "genome." Each forms a vector defining a multi-dimensional space allowing comparisons across projects by measuring the reciprocal distances in this space. A precise, partially quantitative approach to such comparisons could be developed for the field of architecture and urban planning, as already demonstrated for music (Pandora) or art (Artsy). By using the analog tools of diagramming, this study attempts to imagine a possible outcome. By focusing on the creative campus, it imagines the examination the process of imagination itself. 
1 ONIONS, Charles Talbut (Ed.), 1966. The Oxford Dictionary of English Etymology. Oxford: Oxford University Press, p. 514.

2 KOOLHAAS, Rem, 2015. The Smart Landscape: Intelligent Architecture. Artforum.com. 53(8). [Accessed 11 April 2015]. Available at: https://www.artforum.com/print/201504/the-smart-landscape-intelligent-architecture-50735

3 Etymonline.com

4 FLORIDA, Richard, 2005. Cities and the Creative Class. New York: Routledge, pp. $32-37$.

5 See e.g. the city of Chaux near the Arc-et-Senans saltworks. VIDLER, Anthony, 2002. Claude-Nicolas Ledoux. Basel: Birkhäuser, pp. $117-123$

6 AURELI, Pier Vittorio and TATTARA, Mario, 2011. A Simple Heart: Architecture on the Ruins of the Post-Fordist City. Architectural Desig.n 81(1), pp. $110-119$

7 Etymonline.com

8 SASSEN Saskia, 2001. The Global City. Princeton: Princeton University Press, p. 5.

9 KUBO Michael, 2009. Constructing the Cold War Environment. Boston: Harvard University Thesis, pp. $6-7$.

10 0735, C. T., 1966, p. 139.

11 TURNER, Paul V., 1984. Campus: an American planning tradition. Cambridge: The MIT Press, p. 47.

12 Onions, C. T., 1966, p. 139.

13 BOUCKAERT, Remco et al., 2012. Mapping the Origins and Expansion of the Indo-European Language Family. Science 337(6097), pp. 957 - 960.

14 DUNN Michael et al., 2011. Evolved structure of language shows lineage-specific trends in word-order universals. Nature 473(7345), pp. $79-82$

15 PIRANESI, Giammbattista, 1762. Dedicatory letter to Robert Adam. Il Campo Marzio dell'antica Roma. Rome: n.p

16 TAFURI, Manfredo, 1987. The Sphere and the Labyrinth. Cambridge: The MIT Press, p. 34.

$\mathbf{1 7}$ "Geometry is understood here for the first time as 'instrumental,' but this instrumentality undercuts the rational principles that underlie it. The critique of formalism turns back on itself, uncovering the mechanics of an endless chain of combinations that is by itself unable to constrain the combinatory mechanisms. The 'useless machines' of the Campo Marzio turn out to be self-perpetuating." ALLEN, Stanley, 1989. Piranesi's Campo Marzio:
An Experimental Design. Assemblag.e 4(10), p. 97.

18 Pianta di Roma, in PIRANESI, Giammbattista, 1756. Le Antichitò Romane. Rome: Bouchard e Gravier.

19 Onions, C. T., 1966, p. 183.

20 ABEN, Rob, and DE WIT, Saskia, 2001. The Enclosed Garden. Rotterdam: o1o Publisers, pp. $22-24$

21 Onions, C. T., 1966, p. 643.

22 Onions, C. T., 1966, p. 110.

23 Onions, C. T., 1966, p. 222.

24 Source: THOMPSON, D’Arcy

Wentworth, 1945. On Growth and Form. Cambridge: The University Press, pp. $1062-1064$.

25 TURNER, Paul V., 1984. Campus: an American planning tradition. Cambridge: The MIT Press, p. 59.

26 WILSON, Richard G. (Ed.), 1993. Thomas Jefferson's Academical Village. Charlottesville: University Press of Virginia, pp. $11-12$.

27 Turner, P. V., 1984, p. 10.

28 Turner, P. V., 1984, p. 12.

29 ALEXANDER, Christopher, 1966. A city is not a tree. In: Design. 18(206) The citation continues: "There will always be many systems of activity where university life and city life overlap: pub-crawling, coffee drinking, the movies, walking from place to place. In some cases whole departments may be actively involved in the life of the city's inhabitants (the hospital-cum-medical school is an example). In Cambridge, a natural city where university and city have grown together gradually, the physical units overlap because they are the physical residues of city systems and university systems which overlap."

30 Alexander, C., 1966.

31 WHITING, Sarah, 2013. Chicago Superblockism: Chicago's Elastic Grid. In: Shaping the City. Studies in History, Theory and Urban Design. Oxon: Routledge, p. 81

32 "We are about to establish a College near Charlottesville on the land formerly Col. Monroe's, a mile above the town. We do not propose to erect a single grand building, but to form a square of perhaps 200 yards, and to arrange around that pavilions of about 24. by 36. f. [feet] one for every professor ship and his school." JEFFERSON, Thomas, 1817. Letter to James Dinsmore. Jefferson Papers, University of Virginia Archive. Cited in: Thomas Jefferson's Academical Village: The creation of an architectural masterpiece. Charlottesville: University Press of Virginia, p. 15.
33 See FOUCAULT, Michel, 1984. Des espaces autres, Hétérotopies. Architecture, Mouvement, Continuité. 5, pp. $46-49$.

34 "Lying outside of the consecrated ground defined by the city walls, the Campo Marzio had traditionally been the site of funerals and burials. Thus, the urban texture of the Campo Marzio is also characterized by marginality, by otherness. It becomes the locus of all that is excluded from the city proper: the armories and military exercise yards; the stadia and gymnasia; the amphitheaters and circuses; the gardens and pleasure fountains; the crypts and tombs. The conventional institutions of the imperial city are absent. Save in the funerary monuments, there is no civic presence; streets are nonexistent, as is the whole domestic fabric of the city." ALLEN, Stanley, 1989. Piranesi's Campo Marzio: An Experimental Design. Assemblage. 4(10), p. 75

35 MORAVČÍKOVÁ, Henrieta et al., 2020. (Un)Planned Bratislava. Bratislava: Veda, pp. 172 - 227. Accessed at https:// issuu.com/oddelenie.architektury/ docs/200406_maketa_eng?issuu_product=headeroissuu_subproduct $=$ document_pageoissuu_context=signinoissuu_cta $=\log$ _up.

36 On urban artifacts, see ROSSI, Aldo, 1982. The Architecture of the City. Cambridge: The MIT Press, p. 11.

37 For competition details, see e.g. Slovenský stavitel.' 3(4), pp. $150-155$ or Styl. 28(11-12), pp. $181-198$.

38 DULLA, Matúš and MORAVČÍKOVÁ, Henrieta, 2002. Architektúra Slovenska v 2o. storočí. Bratislava: Slovart, pp. $79-8$ o.

39 On amnesia and the persistence of memory, see Allen, S., 1989, pp. $76-77$.

40 For additional information concerning the Square's transformation enabled by changing regulations, see: SZALAY, Peter, 2018. "ASANÁCIA Premeny vyvlastňovacej legislatívy v prvej polovici 20. storočia Bratislave a jej priemet do plánovania hlavného mesta na príklade Námestia slobody." Architektúra \& urbanizmus. 52(1 - 2) pp. $18-35$.

41 See e.g. TÁBOR, Jan and STOLIČNÁ, Elena, 2001. Geschichte eines Platzes. Nextroom.at [online]. [Accessed 19 April 2020]. Available at: https://www. nextroom.at/article.php?id=13320.

42 Archinfo.sk. [online] 2017 [cit. 19. 4. 2020]. [Accessed 19 April 2020]. Available at: https://www. archinfo.sk/diela/revitalizacia-namestia-slobody-v-bratislave-architektonicka-studia.html

43 As euphemized in the competition report: POJTEK, Vladimír, 1942. Bu- dúce univerzitné mesto v Bratislave. Elán. 12(9), p. 4.

44 STRUHÁRIK, Filip, 2016. Bratislava mohla mat' prestížnu univerzitu. Politici a nacionalisti tento plán zničili. Denník $N$ [online]. [Accessed 19 April 2020]. Available at: https://dennikn. sk/548537/bratislava-mohla-mat-prestiznu-univerzitu-politici-a-nacionalisti-tento-plan-znicili/.

45 Due to legal restrictions on academic freedom, CEU moved to Vienna. "If our situation in Hungary is not resolved by December 1, 2018, all U.S.-accredited programs will be offered at our new Vienna campus from September 2019." Cited from Hungarian Legislation FAQ | Central European University. [online]. [Accessed 19 April 2020]. Available at: https:// www.ceu.edu/node/17998.

46 VALPY, Francis Edward Jackson, 1828. An Etymological Dictionary of the Latin Language. London: A. J. Valpy, p. 531.

47 SZALAY, Peter et al., 2014. Vladimi Dedeček Práca/Work [online], 20 min 40 s. [cit. 19. 4. 2020]. [Accessed 19 April 2020]. Available at: https://youtu. be/ZoV1VGv7thQ.

48 SZALAY, Peter et al., 2014. Vladimi Dedeček Práca/Work [online], 5 min [cit. 19. 4. 2020]. [Accessed 19 April 2020]. Available at: https://youtu.be/ ZoV1VGv7thQ.

49 MITÁŠOVÁ, Monika, 2018. Dedeček. Basel: Birkhäuser, p. 410.

50 Mitášová, M., 2018, p. 416.

51 Mitášová, M., 2018, p. 421.

52 Onions, C. T., 1966, p. 184

53 Mitášová, M., 2018, p. 46 


\section{$\mathbf{A} \delta \mathbf{U}$}

ARCHITEKTÚRA \& URBANIZMUS

\section{ČASOPIS PRE TEÓRIU ARCHITEKTÚRY A URBANIZMU}

JOURNAL OF ARCHITECTURAL AND TOWN-PLANNING THEORY

Ročník Volume LIV

Č́slo Number 1- 2 / 2020

REDAKČNÁ RADA EDITORIAL BOARD prof. Dr. Ing. arch. HENRIETA MORAVČíKOVÁ predsedníčka chairwoman

Fakulta architektúry STU, Bratislava

Historický ústav SAV, Bratislava

prof. Mag. phil. Dr. phil. MATTHIAS BOECKL Universität für angewandte Kunst Wien

doc. PhDr. DANA BOŘUTOVÁ, PhD.

Filozofická fakulta UK, Bratislava

prof. Ing. arch. MATÚŠ DULLA, DrSc

Fakulta architektury ČVUT, Praha

doc. Ing. arch. PAVEL HALíK, CSc

Fakulta uměni a architektury TUL, Liberec

doc. Dr. Ing. arch. SONJA IFKO

Fakulteta za arhitekturo Univerza v Ljubljani

doc. PhDr. PETR KRATOCHVÍL, CSC.

podpredseda deputy chairman

Ústav dějin umění AV ČR, Praha

prof. Ing. arch. KAREL MAIER, CSc

Fakulta architektury ČVUT, Praha

prof. Ing. arch. ÁKOS MORAVÁNSZKY, PhD.

Institut für Geschichte und

Theorie der Architektur ETH, Zürich

Dr. PÁL RITOÓK

Magyar Épitészeti Múzeum és Múemlékvédelmi

Dokumentációs Központ, Budapest

Mgr. PETER SZALAY, PhD.

hlavný redaktor managing editor

Historický ústav SAV, Bratislava

prof. Ing. arch. KARIN ŠERMAN, PhD.

Arhitektonski fakultet Sveučilište u Zagrebu

prof. Ing. arch. VLADIMÍR ŠLAPETA, DrSC.

Fakulta architektury, VUT, Brno

prof. Ing. arch. ROBERT ŠPAČEK, CSC.

Fakulta architektúry STU, Bratislava

prof. PhDr. ROSTISLAV ŠVÁCHA, PhD.

Ústav dějin umění AV ČR, Praha
M. arch. Ing.arch. MARIA TOPOLČANSKÁ, PhD.

Akademie výtvarných umění v Praze

prof. Ing. arch. PETR URLICH, CSc. Stavební fakulta ČVUT, Praha

doc. Ing. arch. PETR VORLÍK, PhD.

Fakulta architektury ČVUT, Praha

ADRESA REDAKCIE EDITORIAL ADDRESS

ARCHITEKTÚRA \& URBANIZMUS

Historický ústav SAV,

P. O. Box 198, Klemensova 19, 81499 Bratislava, SK

IČO 166944

www.architektura-urbanizmus.sk

e-mail: architektura-urbanizmus@savba.sk

REGISTROVANÉ V INDEXED AND ABSTRACTED IN Thomson Reuters Arts and Humanities Citation Index, Current Contents - Arts \& Humanities, SCOPUS, RIBA journal index, CEOL, EBSCO

VYDÁVA PUBLISHED BY

C) Historický ústav SAV, Bratislava, jún 2019

TLAČ PRINTED BY

VEDA, vydavatel'stvo SAV

Centrum spoločných činností SAV, Bratislava

ROZŠIRUJE DISTRIBUTED BY

o.z. reflektor

Šancová 17, 81105 Bratislava

Mediaprint-Kapa Pressegrosso, a.s.

Stará Vajnorská 9, 83104 Bratislava

VYCHÁDZA POLROČNE PUBLISHED SEMIANNUALLY EV 3179/09, ISSN 00448680

REDAKCIA EDITOR

Dagmar Slámová

\section{JAZYKOVÁ REDAKCIA EDITTING \\ Katarina Jostičova}

PREKLADY TRANSLATIONS

Martin Tharp (ENG), Eliška Mazalanová (SK),

Pavlina Zelničková, Martina Mojzesová (CZ),

GRAFICKÁ ÚPRAVA LAYOUT

Juraj Blaško

OBÁLKA COVER

Juraj Blaško
ROČNÉ PREDPLATNÉ

SUBSCRIBTION RATE

$18 €+$ poštovné postage $13,80 € / E U$

$25 € /$ mimo EU outside EU

Objednávky SR a ČR

subscription SR and ČR

www.ipredplatne.sk

ostatné krajiny other countries

www.architektura-urbanizmus.sk

CENA JEDNÉHO VÝTLAČKU

SINGLE ISSUE PRICE

$9 €$

Objednávky SR a ČR

subscription SR and ČR

www.ipredplatne.sk

ostatné krajiny other countries

www.architektura-urbanizmus.sk 
ARCHITEKTÚRA \& URBANIZMUS

Časopis Architektúra o urbanizmus uverejňuje štúdie z oblasti teórie architektúry a urbanizmu. Zameriava sa na súčasný stav, históriu, filozofiu a kultúru architektúry a urbanizmu, na otázky ich umeleckého charakteru a na teóriu ich technickej stránky. Zaoberá sa vzt’ahom architektúry a urbanizmu k umeniu, technike a k životnému prostrediu. Publikuje výsledky sociológie a psychológie architektúry a urbanizmu, sociálnej ekológie, výsledky výskumov z oblasti techniky prostredia a z iných disciplín, ktoré prispievajú k rozvoju teoretického ponania v architektúre a urbanizme. Zaoberá sa d’alej metódami hodnotenia kritiky architektonickej a urbanistickej tvorby a hodnotením význačných architektov, architektonických diel a období. Publikuje príspevky o výučbe architektúry a urbanizmu, recenzie odborných kníh, oko aj informácie a správy o dôležitých vedeckých podujatiach. Časopis Architektúra a urbanizmus vydáva Historický ústav Slovenskej akadémie vied v spoluprác s Ústavom dějin umění Akademie věd Českej republiky.

ARCHITEKTÚRA \& URBANIZMUS The journal Architektúra o urbanizmus provides a forum for the publication of papers on theory of architecture and town-planning. The attention is mostly concentrated on the recent state, history, philosophy and culture of architecture and town-planning, as well as on the problems of their art nature and on the theory of their technical aspects. The published papers deal with the relation of architecture and town-planning to art, technology and environment. They also present research results of architecture and town-planning sociology and psychology, social ecology, environment technology and of other theoretical disciplines which contribute to the development of the theoretical knowl edge in architecture and town-planning. The papers further deals with methods of appreciation and criticism of architectural and town-planning activities, as with appreciation of outstanding architects, architectonic works and periods. Papers on architecture and town-planning education, book reviews and information on scientific meetings are involved. The quarterly is published by the Institute of History of the Slovak Academy of Sciences in cooperation with the Art History Institute of the Academy of Sciences of Czech Republic.

\section{Obsah Content}

EDITORIAL EDITORIÁL

2 Henrieta Moravčíková, Peter Szalay (UN)PLANNED CITY

(NE)PLÁNOVANÉ MESTO

VEDECKÉ ŠTÚDIE SCIENTIFIC STUDIES

6 Lýdia Grešáková, Zuzana Tabačková, Zuzana Révészová MAPPING WITH CARE AS AN OUTLINE FOR POST-

NEOLIBERAL ARCHITECTURE METHODOLOGIES - TOOLS OF THE "NEVER-NEVER SCHOOL"

MAPOVANIE SO STAROSTLIVOSŤOU AKO PODKLAD PRE POST NEOLIBERÁLNE ARCHITEKTONICKÉ METODOLÓGIE

- NÁSTROJE „NEVER-NEVER SCHOOL"

20 Peter J. Larkham

BRITISH URBAN RECONSTRUCTION AFTER THE SECOND WORLD WAR: THE RISE OF PLANNING AND THE ISSUE OF "NON-PLANNING"

BRITSKÁ OBNOVA MIEST PO DRUHEJ SVETOVEJ VOJNE: VZOSTUP PLÁNOVANIA A OTÁZKA"NEPLÁNOVANIA"

32 Matěj Spurný

URBAN EXPERTS IN THE BUILDING

OF POST-STALINIST BRATISLAVA

URBÁNNÍ EXPERTI A BUDOVÁNÍ BRATISLAVY

$\checkmark$ ÉRE POSTSTALINISMU

44 Anna Kornélia Losonczy, Regina Balla, Hlib Antypenko, Melinda Benkő

RE-SHAPING BUDAPEST: LARGE HOUSING ESTATES AND THEIR (UN)PLANNED CENTERS

PRETVORIŤ BUDAPEŠŤ: VELKKÉ SÍDLISKÁ

AICH (NE)PLÁNOVANÉ CENTRÁ

56 Karel Maier

PLANNING OF BOHEMIAN REGIONAL CENTRES IN THE PERIOD OF THEIR INDUSTRIALISATION AND MODERNISATION: PLZEŇ AND HRADEC KRÁLOVÉ $1860-1938$

PLÁNOVÁNÍ ČESKÝCH REGIONÁLNÍCH CENTER

V OBDOBÍ INDUSTRIALIZACE A MODERNIZACE:

PLZEŇ A HRADEC KRÁLOVÉ 1860 - 1938
70 Adriana Priatková, Ján Sekan, Máté Tamáska THE URBAN PLANNING OF KOŠICE AND THE DEVELOPMENT OF A 2OTH CENTURY AVENUE MESTSKÉ PLÁNOVANIE V KOŠICIACH A VÝVOJ MESTSKEJ TRIEDY 2O. STOROČIA

89 Klára Brůhová

THE PARLIAMENT FOR PRAGUE - PROPOSALS, COMPETITIONS AND DEBATES ON ITS LOCATION AND ARCHITECTURE

PARLAMENT PRO PRAHU - NÁVRHY, SOUTĚŽE A DEBATY NAD UMÍSTĚNÍM A ARCHITEKTONICKOU FORMOU KOMPLEXU

106 Lina Degtyaryova, Oleg Olashyn

URBAN PLANNING AND CONSTRUCTION OF THE INTERWAR CITY OF UZHHOROD: MISSION INTERRUPTED

PLÁNOVANIE A VÝSTAVBA MESTA UŽHOROD

V MEDZIVOJNOVOM OBDOBII: PRERUŠENÁ MISIA

116 Peter Stec

CREATIVE TRANSFORMATIONS: THE CAMPUS PARADIGM

KREATÍVNE TRANSFORMÁCIE: PARADIGMA KAMPUSU

134 Gonçalo M. Furtado C. L.

THE LEGACY OF THE IGNASI SOLÀ-MORALES

AND THE CONTEMPORARY URBAN DEBATE

ODKAZIGNASIHO SOLA-MORALESA

A SÚČASNÁ DEBATA O MESTE

RECENZIE REWIEVS

145 Zoltán Bereczk

PATTERN RECOGNITION

ROZPOZNÁVANIE VZOROV

148 Peter Szalay

MOC EXPERTOV: KONTINUITY ČI RUPTÚRY

PRED A PO ROKU 1989

THE POWER OF EXPERTS: CONTINUITIES OR RUPTURES

BEFORE AND AFTER 1989

150 Katarína Haberlandová

SANDALOVA MIMORIADNA HĹBKA OSTROSTI

SANDALO'S EXCEPTIONAL DEPTH OF SHARPNESS 